\title{
Linguistic concepts across languages: The category of epistemic adverbs in English and Polish
}

Agata Rozumko

University of Białystok

a.rozumko@uwb.edu.pl

\begin{abstract}
The category of epistemic adverbs has recently received increased attention in both Anglophone and Polish linguistics, but English-Polish contrastive research in this area has so far been rather fragmentary. English and Polish grammars differ considerably in the ways they classify epistemic adverbs. The differences largely result from the different understanding of adverbs as a category, which in English grammar tends to be presented as broad and heterogeneous while in Polish grammar - rather narrow and uniform. Polish equivalents of English epistemic adverbs are classified as particles - a distinct word class with its own characteristic properties. This paper presents an overview of approaches to epistemic adverbs taken in Anglophone and Polish linguistics with the aim of identifying their convergent points and suggesting a framework for a contrastive analysis. In the case of Anglophone research, the focus is largely on discourse studies because epistemic adverbs are usually seen as a discourse category. In Polish linguistics, however, they are analysed within different theoretical frameworks, which is why the discussion will not be limited to one specific methodological school. Reference is also made to more general issues, such as the treatment of adverbs as a category.
\end{abstract}

Keywords: adverb; particle; epistemic; English; Polish.

\section{Introduction}

The category of epistemic adverbs, typically defined as those which refer to the speaker's knowledge, has recently received increased attention in both Anglophone and Polish linguistics. Studies contrasting English epistemic adverbs with their equivalents in other languages (e.g. Dutch, German, French, Swedish) are also numerous (e.g. Nuyts 2001; Simon-Vandenbergen and Aijmer 2007), but English-Polish (and, more generally English-Slavic) contrastive research in this area has so far been rather sparse. The class is an intriguing object of cross- 
linguistic analysis for a number of reasons. First of all, ways of expressing epistemic modality have been shown to be both language and culture specific. Secondly, adverbial epistemics are still less thoroughly explored than modal verbs and the category has not been delineated clearly. In 2006, Wierzbicka (2006: 247) put forward a claim that "the existence of a large class of epistemic adverbs constitutes a peculiar feature of modern English", and referred to it as "a fact of great cultural significance" (2006: 249). Because the criteria used to delimit the category differ not only cross-linguistically but also within Anglophone studies, her claim still remains to be verified. The present study takes a step towards a systematic comparison of English and Polish epistemic adverbs by analyzing their treatment (and the treatment of adverbs in general) in Anglophone and Polish linguistics. Since in Anglophone research epistemic adverbs are largely seen as a category of discourse, the major focus is on discourse studies. However, as the problem also involves more general issues, such as the understanding of adverbs as a category in the two languages, and because studies of epistemic adverbs in Polish have progressed along a different path, the discussion will not be limited to one specific methodological school. The aim of the present study is to identify the convergent points of research into epistemic adverbs conducted in Anglophone and Polish linguistics, and to suggest a framework ${ }^{1}$ for a contrastive analysis.

\section{The category of adverbs in English and Polish grammar}

Most Anglophone publications on adverbs, regardless of the linguistic school which they represent, begin their discussions with statements on the heterogeneous and problematic nature of the class. Similar observations can be found in reference grammars. Huddleston and Pullum (2002: 57) write that it is "the least homogenous of the traditional parts of speech". Kiss (2009: 1) notes that "[t]he category 'adverb' and the function 'adverbial' belong to the most controversial notions of grammatical theory", while Ernst (2002: 1) summarizes the problems saying that "[n]obody seems to know exactly what to do with adverbs [...] almost everyone who has looked at the overall landscape has felt obliged to observe what a swamp it is". Similar observations have been made by Polish linguists. Tokarski (1949), for instance, compared the category of adverbs to an at-

\footnotetext{
${ }^{1}$ The term framework is used here in its rather basic sense to refer to an approach, a type of analysis.
} 
tic where people put things they do not know what to do with. Such statements are, however, less common in more recent Polish grammars, which present the category as rather "neat". The difference results from the changes in the classification of lexemes into word classes which have taken place in Polish linguistics.

In order to outline the differences in approaches to adverbs taken in Anglophone and Polish grammars, it is useful to go back to the characterization of the class done for classical Greek, where adverbs are described as items modifying verbs. This basic characteristic is still included in definitions of adverbs in both English and Polish grammars, but in English grammar, "the modifying function of adverbs has been generalized to other domains, i.e. adverbs not only modify verbal predicates (and by extension sentences), but also adjectives, adverbs, prepositions and nominal expressions" (Haumann 2007: 1), as in the following examples.

(1) verbs: she almost died;

(2) adjectives: an almost inaudible response;

(3) adverbs: she spoke almost inaudibly;

(4) NPs: they ate almost the whole pie;

(5) clauses: surprisingly, the choked voice resumes (Biber et al. 1999: 538; Huddleston and Pullum 2002: 57).

The approach taken in recent Polish publications is closer to the ancient Greek approach. Grochowski et al. (2014: 27) define adverbs as units which enter into a mutual semantic relationship with a verb. In some grammars, e.g. Bańko (2012) and Nagórko (2012), the modifying function of adverbs is extended to adjectives and other adverbs, as in (6-8).

(6) verbs: bardzo chcieć 'to want very much'/ 'to really want'

(7) adjectives: bardzo duży 'very big'

(8) adverbs: bardzo dużo 'really a lot' (Bańko 2009: 119) 
Those lexemes which modify noun phrases, prepositional phrases and clauses, called adverbs in English reference grammars, are classified as particles in Polish grammar books. At the same time, Polish scholars note numerous similarities between adverbs and particles. Nagórko (2012: 118) writes about frequent cases of homonymy between the two categories, and observes that the only way to distinguish between them is to analyze their syntactic position and function. One of the examples she discusses is $j u \dot{z}$ 'already', which is an adverb in (9), where it modifies a verb, but a particle in (10), where it modifies a prepositional phrase.

(9) Kiedyś już widziałam ten film. 'I have already seen this film.'

(10) Pismo ukazuje sie już od roku.'This journal has been in existence already for a year.'

The adverb-particle field as presented above seems quite well defined in Polish. However, as outlined in Section 5., recent studies of Polish particles demonstrate that it is in fact considerably more complex. What is clear is that different treatments of the category of adverbs in Anglophone and Polish linguistics result in different understandings of the notion of epistemic adverbs in the two languages.

\section{Epistemic adverbs in English grammar}

Like other markers of epistemic modality, epistemic adverbs are usually defined as those which refer to "someone's world knowledge, typically that of the speaker" (Narrog 2012: 8). They express the nature and degree of the speaker's commitment to the truth of the proposition (cf. Huddleston and Pullum 2002: 767). In other words, the speaker uses them to express certainty or doubt that the proposition is true. English reference grammars discuss them under different headings, but they are always included in sections on adverbs and the examples provided usually overlap. Quirk et al. (1985: 620-621) include them in the category of content disjuncts. The category comprises two subcategories: (1) disjuncts expressing degree of truth (which is where epistemic adverbs belong); and (2) disjuncts expressing value judgement, comprising such items as rightly, 
correctly, incorrectly, justly, unjustly, wrongly, cleverly, wisely. Disjuncts expressing degree of truth are divided into:

(a) adverbs expressing conviction: admittedly, assuredly, avowedly, certainly, decidedly, definitely, incontestably, incontrovertibly, indeed, indisputably, indubitably, surely, unarguably, undeniably, undoubtedly, unquestionably, clearly, evidently, manifestly, obviously, patently, plainly;

(b) adverbs expressing some degree of doubt: allegedly, arguably, apparently, conceivably, doubtless, likely, maybe, most likely, perhaps, possibly, presumably, purportedly, quite likely, reportedly, reputedly, seemingly, supposedly, very likely;

(c) adverbs used by the speaker to judge what he says to be true or false: actually, really, factually, only apparently, formally, hypothetically, ideally, nominally, officially, ostensibly, outwardly, superficially, technically, theoretically, basically, essentially, fundamentally (Quirk et al. 1985: 621).

Epistemic adverbs are those expressing conviction and doubt, listed in a) and b), though the classification criteria used for the items listed in c) are not very precise. Quirk et al. (1985) offer no explanation as to why apparently and only apparently are listed in different groups. Likewise, it is not entirely clear why the authors treat most likely, quite likely and very likely as separate epistemics, at the same time omitting such items as most clearly and most obviously.

Biber et al. (1999) use the term epistemic stance adverbials to refer to the items in question, but their category is broader, and also includes adverbials which mark actuality and reality (really, in fact), limitation of the proposition (in most cases), etc. Within the class, they distinguish a group of adverbials expressing doubt and certainty (no doubt, undoubtedly, certainly, probably, maybe, perhaps, arguably, decidedly, definitely, incontestably, incontrovertibly, most likely, very likely, quite likely, of course, I guess, I think), and those which refer to the source of knowledge: evidently, apparently, reportedly, reputedly (Biber et al. 1999: 855). Their list is clearly not intended to be complete, as numerous epistemic adverbs are omitted from it, e.g. obviously, presumably.

Huddleston and Pullum (2002: 767) refer to epistemic adverbs as modal adjuncts, noting that most modal adjuncts express epistemic meanings. Their list 
includes 32 items grouped according to the degree of certainty they express. The list of strong items includes: assuredly, certainly, clearly, definitely, incontestably, indubitably, ineluctably, inescapably, manifestly, necessarily, obviously, patently, plainly, surely, truly, unarguably, unavoidably, undeniably, undoubtedly, unquestionably. A lower level of certainty is postulated for apparently, doubtless, evidently, presumably, seemingly, followed by arguably, likely, prob$a b l y$. Adjuncts expressing the lowest level of certainty include conceivably, maybe, perhaps, possibly (Huddleston and Pullum 2002: 768). Contrary to Quirk et al. (1985), Huddleston and Pullum (2002) exclude allegedly from their list, explaining that: "allegedly absolves me from responsibility for the residual proposition: the latter has the status of an allegation, and I can't say whether it is true" (Huddleston and Pullum 2002: 769). The same reason may have motivated the omission of reportedly and reputedly, both of which signal that the speaker is not to be held responsible for to the content of the proposition. However, the authors do not discuss the two adverbs.

Overall, the three reference grammars list 45 epistemic adverbs: admittedly, allegedly, apparently, arguably, assuredly, avowedly, certainly, clearly, conceivably, decidedly, definitely, doubtless, evidently, incontestably, incontrovertibly, indeed, indisputably, indubitably, ineluctably, inescapably, likely, manifestly, maybe, necessarily, no doubt, obviously, of course, patently, perhaps, plainly, possibly, presumably, probably, purportedly, reportedly, reputedly, seemingly, supposedly, surely, truly, unarguably, unavoidably, undeniably, undoubtedly, unquestionably. While this list is definitely helpful in illustrating what is to be meant by epistemic adverbs in Anglophone linguistics, it does not fully reflect the classification and description problems the category poses. Findings from discourse studies demonstrate that the adverbial status of "modal adverbs" is more problematic than their presentation in reference grammars may suggest. Martin and Rose (2003) note that modality creates space for negotiation and mediation. Numerous functions of epistemic adverbs are activated during the process of communication, and they go far beyond the role ascribed to them in grammar books, i.e. the expression of certainty (Mortensen 2012). By using modal expressions, the author invites alternative voices and different points of view to the discussion $\mathrm{s} /$ he initiates. Thus, modal adverbs play important roles in interpersonal communication - a property which has so far been treated marginally in English-Polish contrastive research and one which definitely deserves closer scrutiny. The sections which follow outline the ways in which pragmatic properties of modal adverbs are reflected in recent attempts at their description and classification in Anglophone and Polish linguistics. 


\section{Epistemic adverbs and particles in English}

Both English and Polish grammars use the term particle to refer to uninflected words (cf. Huddleston and Pullum 2002: 280; Bańko 2009: 118), but the specific referents of the term are different in the two languages. Huddleston and Pullum (2002: 280) define particle as "a one-word phrase functioning as complement of the verb". Their list of particles includes prepositions (e.g. She brought down the bed), some adjectives (They cut short their holiday) and a small number of verbs (She let go his hand) (Huddleston and Pullum 2002: 280). Howev$\mathrm{er}$, it is not this understanding of the term which is relevant for the purposes of this study.

The term particle has a wide currency in discourse studies, where it is used to refer to expressions which guide the addressee through the discourse by showing connections between utterances. Such expressions are called discourse particles (Hansen 1998; Archakis 2001; Diewald 2006; Fischer 2006), pragmatic particles (Foolen 1996), discourse markers (cf. Lenk 1997; Hansen 1998; Fischer 2014; Lewis 2006) pragmatic markers (Aijmer 2009; Aijmer and Simon-Vandenbergen 2009). Some scholars characterize the functions of discourse markers as extending beyond indicating relations between elements of discourse: Schiffrin (1987) notes that they refer to the relation between the speaker and hearer, Ochs (1996) writes that they express epistemic stance, Jucker and Ziv (1998) add that they act as prompters, fillers, etc. In most descriptions, discourse markers do not constitute a uniform class. Lewis notes that the group comprises "subtypes of sentence adverbials, parentheticals, conjunctions, or transparent predicates" (Lewis 2006: 44), and provides the following examples of the category: Well, I mean, so, in fact, though, of course, anyway, actual$l y$, on the other hand. Lewis's (2006) examples show that she identifies discourse markers on the basis of functional criteria. This tendency seems to prevail in Anglophone discourse studies: Hansen (1998) writes that discourse markers form a functional-pragmatic category; Fischer (2006: 5) refers to the term discourse particles as "purely functional".

In addition to the term discourse (or pragmatic) particle, discourse studies use the term modal particle. With reference to English, it seems to have first been used by Aijmer (1997) in her study of the functions of I think (cf. Traugott 2007). She considers the category to be "a subclass of pragmatic markers" (Aijmer 2009: 111), a term which she treats as equivalent to discourse markers. Generally, modal particles are said to express epistemic modality and "the speaker's attitude to the proposition" (Hasselgård 2006: 95), but the specific 
ways in which the term is used differ among discourse scholars, and the related discourse categories seem to "shade into one another" (Foolen 1996 online).

Differences between discourse particles and modal particles have been explained with reference to their syntactic position. Definitions developed for such languages as German, Danish and French say that modal particles are restricted to clause-internal positions (cf. Hansen 1998). Such a narrow view automatically excludes many English "candidates for particles", which is why English has been said not to have any modal particles (cf. Traugott 2007; Aijmer 2013). Most researchers, however, perceive the difference to be of a functional and pragmatic character and use the term modal particle to refer to some of the items traditionally classified as modal adverbs.

Aijmer (2013), for instance, argues that of course, which is usually classified as a modal adverb, can also function as a discourse particle and a modal particle. She suggests that "Of course as a discourse marker is used at boundaries of the discourse (signaled by utterance-initial position) and signals connection between utterance units (adversative, concessive or resultative function). The modal particle of course, on the other hand, is used to metapragmatically comment on the proposition in the context of the language users' common ground" (Aijmer 2013: 102). Her examples of the use of of course as a discourse marker include $O$ f course you haven't been here long, but you'll have heard of Davina Flory?" (Aijmer 2013: 94), and as a modal particle: "If global decisions are to have legitimacy, then of course they must be representative" (Aijmer 2013: 101). While Aijmer (2013: 89) writes that of course has uses as "a modal adverb, discourse marker and modal particle", she mainly focuses on its use as a discourse marker and modal particle, and does not specify which (if any) of its uses are adverbial in character. In her discussion of of course as an adverb, both in Aijmer (2009) and Aijmer (2013), she only refers to its description in Quirk et al. (1985), but it is not entirely clear if any specific adverbial functions performed by of course are to be identified. Aijmer (2009: 127) concludes that "English has modal particles 'which look like adverbs' but can be distinguished from those on the basis of function as well as on the patterns where they occur". In Simon-Vandenbergen and Aijmer (2002/2003: 19), of course is treated as a pragmatic marker (i.e. discourse particle) in all its uses; in Simon-Vandenbergen and Aijmer (2007), it is listed as one of English adverbs of certainty. Thus, in their description of of course, Aijmer and SimonVandenbergen seem to use $a d v e r b$ as a convenient traditional label, without any specific pragmatic functions assigned to it. 
However, Aijmer $(2009,2013)$ also notes that the difference between epistemic adverbs and modal particles is usually explained with reference to a grammaticalization theory (e.g. Hoye 1997; Diewald 2006). Traugott (2012: 18) observes that the development of numerous discourse markers is a result of grammaticalization - an explanation which she originally suggested for the developmental path of several markers, such as indeed, in fact, actually (Traugott 1995). Many discourse markers were originally "referential expressions", then they developed into epistemic adverbs with procedural functions, and finally became even more procedural "epistemic linkers" (Traugott 2012: 19; cf. also Hopper and Traugott 2003). Erman and Kotsinas (1993), Aijmer (1996) and Beeching (2012) prefer the term pragmaticalization to refer to the processes responsible for the development of discourse markers. However, Traugott (2012) argues that such views result from a different understanding of the nature of grammaticalization. Scholars who explain the development of discourse markers with reference to pragmaticalization stress the functional character of the change, assuming grammaticalization to be a formal change involving "reduction and increase in dependency" (Traugott 2012: 19), while grammaticalization can also be assumed to be a primarily functional change.

Hoye (1997) suggests that adverbs "more clearly [than particles] express lexical meanings in their characterization of the speaker's orientation, commentwise or content-wise, towards his utterance" (Hoye 1997: 209-210). Particles, in contrast, show a greater degree of grammaticalization. He also notes that they are "restricted to medial position and the verb phrase" and that most of them "may additionally function as sentence adverbs (adjuncts and disjuncts) according to their position in the sentence and the general context" (Hoye 1997: 212). In Hoye's view, modal particles should be treated as "a special subset of modal adverbs rather than an entirely separate word class" (Hoye 1997: 212).

Wierzbicka (2006), in contrast, insists on the need to separate between the two categories. She argues that their pragmatic functions are entirely different, which is why treating them as members of the same class blurs the characteristic properties of each of the two categories. Modal particles, like other discourse markers, are interactional, dialogic and addressee-oriented, while epistemic adverbs are monological, speaker-oriented and do not encourage interaction (Wierzbicka 2006: 287). In fact, Wierzbicka's description of modal particles largely agrees with that proposed by Aijmer (2009: 111), who also notes that they "have textual and interpersonal functions". However, while Aijmer (2009) focuses on discourse particles, Wierzbicka's (2006) attention is primarily on epistemic adverbs. She argues that "the wealth of epistemic adverbs" is "a cultur- 
ally significant peculiarity of modern English" (Wierzbicka 2006: 287), caused by the importance of the Enlightenment (and its emphasis on the limitations of human knowledge) in the process of shaping Anglo speech patterns. She disagrees with Nuyts (2001: 56) who said (without separating epistemic adverbs from modal particles), that the class of epistemic adverbs is "remarkably comparable" in English, Dutch and German. Epistemic adverbs, whose functions, in Wierzbicka's opinion, reflect characteristically Anglo ways of speaking, "indicate that the speaker has no wish to 'impose' his or her point of view on the addressee" (Wierzbicka 2006: 287). She proposes the following syntactic and semantic criteria for identifying epistemic adverbs:

1. They can be used sentence-initially.

2. They can be used sentence-internally (after the auxiliary if there is one, otherwise before the main verb).

3. They cannot be used in questions.

4. They include in their semantic structure the components "I think" and "I don’t say I know" (Wierzbicka 2006: 291).

Wierzbicka's (2006: 248) list of epistemic adverbs includes: arguably, admittedly, apparently, allegedly, clearly, certainly, conceivably, evidently, indisputably, manifestly, obviously, probably, presumably, reportedly, seemingly, undoubted$l y$, unquestionably. The examples of items which she classifies as modal particles are less numerous and include indeed, maybe, surely, perhaps, of course (Wierzbicka 2006: 287). Wierzbicka's criteria may be treated as a good starting point in the process of identifying epistemic adverbs, but they also need to be verified. For example, obviously, which she classifies as an epistemic adverb, can be used as a tag, as in the following example from the British National Corpus: But ... but you don 't agree with them, obviously? (BNC HHA 2243). When used in this way, it clearly has a dialogic function.

Wierzbicka (2006) does not pay much attention to the morphological form of the items she classifies as epistemic adverbs. In fact, she notes that "in form, some pragmatic particles can be indistinguishable from adverbs" (Wierzbicka 2006: 291), but it can be noticed that they all end in - $l y$, which strengthens their affinity with adverbs. Among the items classified by Wierzbicka as particles, there are also those which end in -ly, such as surely (and certainly in some of its uses), but most of them do not have any characteristic morphological forms. Unlike Aijmer (1997), Wierzbicka (2006) does not include epistemic verbal phrases or clauses in her list of modal particles. 
A similar approach is found in Weydt (2006: 206), who writes that "only single words, not clauses, are considered to be particles. Word groups like English I mean, you know, ... are not particles, in spite of the undisputed fact that they can occupy the place of a particle, replace it, and be replaced by it". Weydt (2006: 206) prefers to see particles as a word class "just like other linguistic terms such as verb and noun", an approach which is adopted in German linguistics. Most discourse scholars, however, use functional criteria to identify modal particles, and treat them as a discourse category, not a word class.

\section{Particles and related phenomena in Polish linguistics}

Most of the recent studies of particles in Polish linguistics have focused on establishing the criteria for distinguishing particles as a word class. Thus, the aims and motivation of Polish studies have been different from those of much Anglophone research. Originally, Polish grammars used the term particle to refer to all uninflected word classes, i.e. adverbs, prepositions, conjunctions and interjections (Bańko 2012: 118). In the 19th century, the category was redefined to apply to a small group of lexemes which did not show the properties of any of the traditional word classes, such as $c z y$ (a question word used in yes/no interrogatives, also 'if'), niech (roughly 'let', as in Let there be light), nie ('no'). Since then, it has gradually been absorbing other lexemes which are difficult to classify, mostly adverbs and conjunctions which do not possess the prototypical features of the categories they were earlier assigned to. In 20th-century publications, the class expanded so considerably, that some authors described it as a "a rubbish sack" (cf. Jodłowski 1971; Bańko 2012). There were numerous attempts to redefine word classes in 20th-century Polish linguistics. Overall, as observed by Grochowski et al. (2014: 25), the history of the relationship between adverbs and particles in Polish linguistics can be summarized as a change from unity to complete separation. Important contributions to the understanding of the category in Polish came from Grochowski (e.g. 1986) and Wajszczuk (2000, 2005, 2010). Grochowski's many years of research on particles culminated in a recent dictionary of Polish particles (Grochowski et al. 2014), which offers a comprehensive account of the types of particles in Polish and summarizes the numerous attempts at defining the category in Polish linguistics. Originally, Grochowski attempted to identify particles as a category solely on the basis of formal syntactic criteria. In Grochowski et al. (2014), these are supplemented with an analysis of semantic properties of the identified lexical units. Particles are said to refer to 
the speaker and comment on the content of the proposition. They co-occur with a number of grammatical classes, while adverbs only enter into a mutual syntactic relation with the verb.

Grochowski et al. (2014), as well as Wajszczuk (2000, 2005, 2010), and earlier Wierzbicka (1971), see particles as elements of the metatext. This seems to be one of the most important differences in the description of the items in question between Anglophone and Polish linguistics. As observed by Tutak (2003: 38 ), the category of discourse (and consequently discourse studies) is not as well established in Polish linguistics as it is in Anglophone research. As a result, epistemic adverbs (or particles, to use Polish terminology) are rarely referred to as a discourse category. The term metatext has been created on analogy to the term metalanguage to describe the level of text which is used to refer to the text itself (Piekarczyk 2015: 15). Metatextual expressions show relations between different parts of the text as well as the speaker's attitude towards his/her own words (cf. Wierzbicka 1971). Studies of metatext, as Tutak (2003: 46) explains, tend to see text as a static structure, while discourse studies treat it as a dynamic phenomenon. Tutak (2003) adds, however, that it is possible to interpret metatext and discourse as equivalent terms if, as some linguists prefer it, text is understood as a dynamic structure. Piekarczyk $(2015: 17)$ observes that metatext is increasingly treated as a system which influences text interpretation, which brings Polish studies closer to Anglophone discourse analysis. In fact, the category of metatext is also occasionally employed in Anglophone discussions of discourse markers but it is not a dominant one. For instance, Traugott (1995: 5) notes that discourse markers "do metatextual work", i.e. "they allow speakers to display their evaluation not of the content of what is said, but of the way it is put together". The aims and findings of Anglophone and Polish studies are, therefore, not necessarily incomparable.

One of the recent attempts to classify metatextual expressions in Polish is Wajszczuk (2005). She divides them into metapredicative operators, metatextual operators and metatextual commentaries. Metapredicative operators (Pol. operatory metapredykatywne) function within the syntactic structure of a sentence, and include such items as intensifiers (e.g. bardzo 'very') and approximators (niemal 'almost'). Metatextual operators (Pol. operatory metatekstowe) function above the level of sentence structure and comprise conjunctions and particles. Both metapredicative and metatextual operators are individual words (lexemes). More complex expressions of a metatextual character, e.g. verbal phrases, such as ściśle rzecz biorac 'strictly speaking' form a category of metatextual commentaries (Pol. komentarze metatekstowe). Wajszczuk's metatextual operators 
and commentaries seem to correspond to the Anglophone category of discourse markers. Grochowski et al. (2014: 29) note, however, that the different layers of the metatext remain largely unexplored in Polish linguistics.

In their dictionary, Grochowski et al. (2014: 34-36) group Polish particles into five semantic "nests", which they see as a convenient way of presenting the semantics of the items in question rather than their formal classification. The first "nest" of particles which they identify - epistemic particles - roughly corresponds to the category of epistemic adverbs in English. The five groups they distinguish include:

1. epistemic particles (Pol. partykuty epistemiczne), i.e. items connected with the speaker's awareness of his/her state of knowledge, e.g. prawdopodobnie 'probably', niewatpliwie 'undoubtedly';

2. particles commenting on the process of speaking (e.g. the speaker's the choice of vocabulary) (Pol. partykuly komentujace mówienie), e.g. niejako 'in a way', dostownie 'literally', w zasadzie 'actually';

3. connecting particles, i.e. those showing relations between elements of an utterance (Pol. partykuly konkluzywne): zatem 'therefore', niemniej 'nevertheless';

4. particles of comparison (Pol. partykuly porównania): też 'too', przede wszystkim 'first of all';

5. complementing particles: those which introduce additional, originally unplanned information (Pol. partykuty uzupetniania): co więcej 'what is more', nawiasem mówiac 'by the way'.

Epistemic particles are further subdivided into 9 groups: (1) hypothetical (Pol. hipotetyczne): pewnie, pewno, prawdopodobnie, przypuszczalnie, zapewne; (2) inferential (Pol. inferencyjne): najwidoczniej, najwyraźniej, widać, widocznie; (3) particles allowing disagreement and the possibility that the proposition is not true (Pol. niewykluczajace): bodaj, bodajże, być może, chyba, może; (4) confident (Pol. pewnościowe): ani chybi, bez watpienia, jak nic, na bank, na mur beton, na pewno, na sto procent, niechybnie, niewatpliwie, z pewnościa; (5) polemic (Pol. polemiczne): de facto, tak naprawde, $w$ gruncie rzeczy, $w$ istocie, $w$ istocie rzeczy, w rzeczywistości; (6) confirmatory (Pol. potwierdzajace): fakt 
faktem, faktycznie, istotnie, rzeczywiście, w rzeczy samej; (7) particles of conviction (Pol. przeświadczenia): ma się rozumieć, naturalnie, oczywiście, rzeczjasna; (8) referring particles (Pol. referujace): jakoby, podobnież, podobno, ponoć, rzekomo; and (9) particles excluding the possibility that conflicting statements may be true (Pol. wykluczajace): autentycznie, doprawdy, naprawdę. An attempt at testing the validity of their categorisation for English adverbs requires extensive analysis and, as such, it is far beyond the scope of this study. However, some general observations concerning the compatibility of this approach with those taken by Anglophone studies can be made at this stage.

Grochowski et al.'s (2014) list comprises both individual words, such as niewatpliwie 'undoubtedly', and structurally more complex items, like noun phrases, such as rzecz jasna (lit. 'clear thing', roughly: 'sure thing'), prepositional phrases, e.g. wistocie rzeczy (lit. 'in the essence of things', roughly: 'as a matter of fact'), as well as colloquialisms, e.g. na mur beton (roughly: 'sure as concrete'/' $100 \%$ sure') and na bank (roughly: 'sure as in a bank'). Such treatment has both its advantages and disadvantages. Focus on the functional rather than formal properties of the items largely agrees with Anglophone approaches, and makes Grochowski et al.'s (2014) collection comparable with Anglophone studies. However, the inclusion of colloquial expressions, which is likely to have been motivated by the lexicographic character of the work, makes the list rather selective, as the items provided have a number of synonyms in colloquial Polish.

A comparison of Grochowski et al.'s (2014) list with the items listed by English reference grammars also demonstrates that linguists differ in the way they understand the term epistemic. English equivalents of Grochowski et al.'s (2014) polemic particles, e.g. tak naprawde 'in fact, as a matter of fact', w rzeczywistośc $i$ 'in reality' are not usually considered to be epistemic adverbs, though Biber et al. (1999) list in fact in their category of epistemic stance adverbials. Lewis (2006), on the other hand, classifies it as a discourse marker. As noted by Narrog (2012: 8), "there is no agreement in the literature on how narrow or wide epistemic modality should be conceptualized", therefore the notion always needs clarification, particularly in contrastive studies.

Some of the subcategories distinguished by Grochowski et al. (2014) are also used in Anglophone studies. They group epistemic particles on the basis of the level of certainty which they express (hypothetical, confident, particles of conviction), which is a common way of treating epistemic adverbs in Anglophone linguistics (cf. Wierzbicka 2006). They also identify a category of "inferential particles", which corresponds to English evidential adverbs, comprising 
obviously, clearly, evidently, etc. (cf. Hoye 1997; Simon-Vandenbergen and Aijmer 2007). Grochowski et al.'s (2014) group of "referring particles" is equivalent to hearsay adverbs, comprising apparently, reportedly, etc. (e.g. Wierzbicka 2006). The category they refer to as "confirmatory particles" is largely equivalent to what Simon-Vandenbergen and Aijmer (2007) call expectation adverbs, including such items as of course and naturally. However, while the confirmatory function of the epistemics grouped in this category seems to be their distinctive feature in both classifications, the membership of this category in English and Polish is different. For example, Simon-Vandenbergen and Aijmer (2007) do not classify indeed as an expectation adverb even though they observe that it "has a function of referring back, confirming and emphasizing some proposition which is not new in the context" (Simon-Vandenbergen and Aijmer 2007: 115). Its closest Polish equivalent, rzeczywiście is classified as a confirmatory particle by Grochowski et al. (2014). A comparison of Anglophone and Polish classifications of epistemic adverbs (or particles) is likely to shed some light on the semantic and pragmatic properties of individual items. However, a precise identification of the counterparts of the particles in the two languages requires more extensive research.

Although Grochowski et al.'s (2014) presentation of particles may suggest that the class is quite clearly delineated in Polish, the authors themselves admit that some items still pose classification problems. Reservations concerning the characteristics of particles expressed in recent studies suggest that it may in some cases be more appropriate to talk about the adverb-particle continuum rather than adverbs and particles as entirely separate classes. Danielewiczowa (2012: 16), for instance, argues that between regular adverbs (those which modify verbs) and particles (units of a metatextual character) there is a vast unexplored area of "intermediate phenomena" (quasi-adverbs). It is within this field that she locates the object of her study: adverbial metapredicates (Pol. metapredykaty przystówkowe). She uses this term to refer to metatextual uses of otherwise regular adverbs, e.g. Pol. jawnie 'manifestly, openly'. Jawnie is an adverb in: Nazizm zabijat jawnie, a komunizm po cichu 'Nazism killed people openly, while communism did it secretly' and a metapredicate in Twoja wypowiedź jawnie przeczy logice 'Your answer manifestly contradicts logic' (Danielewiczowa 2012: 169-170). Danielewiczowa argues that such adverbial metapredicates are epistemic in character as they all refer to the speaker's knowledge. In fact, Danielewiczowa $(2008,2012)$ is one of the few Polish linguists who use the term epistemic adverbs (Pol. przystówki epistemiczne) in their works. She considers it to be a useful label for those items which she calls 
"genetic adverbs", i.e. items which, unlike many "proper" particles, have characteristic adverbial forms, i.e. they end in $-e$ or $-o$, like typical Polish adverbs, and have corresponding modal adjectives, e.g. przypuszczalnie 'presumably' (Adj. przypuszczalny). She situates them between typical adverbs and typical particles, in a field where the demarcation lines have not yet been set properly. Danielewiczowa (2012) stresses the dynamic character of adverbs as a category and their tendency to expand into the metatextual level of language, a process which in Anglophone linguistics is explained with reference to the framework of grammaticalization and pragmaticalization (cf. Traugott 2012). Infrequent references to grammaticalization and pragmaticalization in discussions of Polish epistemic particles constitute another characteristic difference between Anglophone and Polish studies of the category. Polish scholars tend to treat pragmatic properties of epistemic particles rather marginally, considering them to be secondary to a semantic and syntactic description (cf. Danielewiczowa 2012: 51). The pragmatic characteristics of particles offered by Grochowski et al. (2014) are limited to statements regarding the register where individual particles are likely to occur: colloquial or formal. Some pragmatic properties of selected Polish epistemics (not only particles) have, however, been identified by Tutak (2003), who notes that epistemic meanings are often actualized during the process of speaking. However, the specific functions of individual modal particles in the speaker-hearer interaction still remain to be identified.

\section{Summary and conclusions}

The overview of Anglophone and Polish research into epistemic adverbs presented in the previous sections is necessarily both multifaceted and selective, which is why a brief summary of the main points seems useful. In English linguistics, which treats the category of adverbs as broad and heterogeneous, items such as certainly and obviously are classified as adverbs (modal adverbs/ epistemic adverbs). Because of their pragmatic properties and their role in discourse (expressing the speaker's attitude to the proposition, and marking connections between elements of discourse), they are said to also function as modal particles and discourse markers. Epistemic adverbs are said to become modal particles and discourse markers as a result of grammaticalization or, as some linguists prefer to call it, pragmaticalization. 
In Polish linguistics, which understands the category of adverbs narrowly as items which modify verbs (in some approaches also adverbs and adjectives, but not nouns, prepositions or clauses), equivalents of English modal adverbs are classified as particles. Particles are considered to be a distinct word class, whose distinguishing property as presented in most recent descriptions is their metatextual character. Unlike their Anglophone counterparts, Polish particles are not usually analysed within discourse studies because these are not as well established in Polish linguistics as they are in English. Most Polish studies of particles have focused on identifying the criteria for delimiting particles as a grammatical category. The criteria employed are primarily semantic and syntactic in character. Pragmatic properties of epistemic particles have so far been less thoroughly described. Polish scholars frequently note the dynamic nature of the category of adverbs but they tend not to refer to grammaticalization or pragmaticalization as the processes responsible for turning adverbs into particles.

However, even though Anglophone and Polish studies of epistemic adverbs use different theoretical frameworks, they seem to share some goals. Their findings also overlap in many cases. What Anglophone linguistics calls discourse markers, Polish linguistics terms metatextual expressions (cf. Wajszczuk 2005; Żabowska 2009). The discussion of the layers of the metatext which has recently begun in Polish linguistics (e.g. Wajszczuk 2005; Żabowska 2009; Danielewiczowa 2012) largely mirrors the concerns of Anglophone discussions of the types of discourse markers (cf. Fischer 2006). Some of the specific types of epistemic adverbs distinguished in Anglophone linguistics have also been proposed for Polish epistemic particles. For instance, the categories of evidential, hearsay and expectation (or: confirmatory) adverbs have been identified in both languages. The specific membership of these (and other) subcategories and the counterparts of individual epistemic adverbs in the two languages remain to be established, but the findings obtained for both languages are considerable and comparable enough to constitute a solid basis for a contrastive study. Contrastive studies need to pay considerable attention to functional and pragmatic properties of epistemic adverbs in both languages since many of their functions are actualized at the moment of speaking. Because of the multiplicity of roles which epistemic adverbs play in interpersonal communication, the pragmaticfunctional framework seems particularly useful in cross-linguistic research. It is also useful from the perspective of intercultural communication as ways of expressing modality and functions of different modal markers tend to be culture specific. 


\section{References}

Aijmer, K. 1997. "I think - an English modal particle". In: Swan, T. and W.O. Jansen (eds.), Modality in Germanic languages (Trends in Linguistics, Studies and Monographs 99). Berlin/New York: Mouton de Gruyter. 1-47.

Aijmer, K. 2009. "Does English have modal particles?" In: Kehoe, A. and A. Renouf (eds.), Corpus linguistics: Refinements and reassessments. New York/Amsterdam: Rodopi. 111-130.

Aijmer, K. 2013. "Analyzing modal adverbs as modal particles and discourse markers". In: Degand L., B. Cornillie and P. Pietrandrea (eds.), Discourse markers and modal particles. Categorization and description. Amsterdam/Philadelphia: John Benjamins. 89-106.

Aijmer, K. and A.-M. Simon-Vandenbergen, 2009. “Discourse markers”. In: Handbook of pragmatics online. John Benjamins.

Archakis, A. 2001. "On discourse markers: Evidence from modern Greek”. Journal of Pragmatics 33. 1235-1261.

Bańko, M. 2012. Wyktady z polskiej fleksji [Lectures in Polish inflectional morphology]. Warszawa: PWN

Beeching, K. 2012. "Semantic change. Evidence from false friends". In: Lauwers, P., G. Vanderbauwhede and S. Verleyen (eds.) Pragmatic markers and pragmaticalization. Lessons from false friends. Amsterdam/Philadelphia: John Benjamins. 11-36.

Biber, D., S. Johansson, G. Leech, S. Conrad and E. Finegan, E. 1999. Longman grammar of spoken and written English. Harlow: Longman.

Danielewiczowa, A. 2008. "Jak nie należy opisywać przysłówków epistemicznych?" [How not to describe epistemic adverbs?] Wiener Slawitischer Almanach 72, Lexikalishe Evidenzialitäts-Marker in slavischen Sprachen. 109-128.

Danielewiczowa, M. 2012. W głąb specjalizacji znaczeń. Przysłówkowe metapredykaty atestacyjne. [Probing into specialization of meanings. Adverbial attestation metapredicates] Warszawa: Katedra Lingwistyki Formalnej UW.

Diewald, G. 2006. "Discourse particles and modal particles as grammatical elements." In: Fischer, K. (ed.), Approaches to discourse particles. Amsterdam: Elsevier. 403425.

Erman, B. and U.-B. Kotsinas. 1993. "Pragmaticalization: the case of ba' and you know". Studier i modern språkvetenskap 10. 76-93.

Ernst, T. 2002. The syntax of adjuncts. Cambridge: Cambridge University Press.

Fischer, K. 2006. "Towards an understanding of the spectrum of approaches to discourse particles: Introduction to the volume". In: Fischer, K. (ed.), Approaches to discourse particles. Amsterdam: Elsevier. 1-20.

Fischer, K. 2014. "Discourse markers". In: Schneider, K.P. and A. Barron (eds.), Pragmatics of discourse. Berlin/Boston: De Gruyter Mouton. 271-294.

Foolen, A. 1996. "Pragmatic particles". In: Handbook of pragmatics online. John Benjamins.

Grochowski, M. 1986. Polskie partykuły. Składnia, semantyka, leksykografia [Polish particles. Syntax, semantics, lexicography].Wrocław: Ossolineum. 
Grochowski, M., A. Kisiel and M. Żabowska. 2014. Słownik gniazdowy partykut polskich [A nest dictionary of Polish particles]. Kraków: Polska Akademia Umiejętności.

Hansen, M.-B.M. 1998. The function of discourse particles: A study with special reference to spoken standard French. Amsterdam/Philadelphia: John Benjamins.

Hasselgård, H. 2006. "“Not now' - On non-correspondence between the cognate adverbs now and nå". In: Aijmer, K. and A.-M. Simon-Vandenbergen (eds.), Pragmatic markers in contrast. Amsterdam: Elsevier. 93-113.

Haumann, D. 2007. Adverb licensing and clause structure in English. Amsterdam/ Philadelphia: John Benjamins.

Hopper, P.J. and E.C. Traugott. 2003. Grammaticalization. (2nd ed.) Cambridge: Cambridge University Press.

Hoye, L. 1997. Adverbs and modality in English. London/ New York: Longman.

Huddleston, R. and G.K. Pullum. 2002. The Cambridge grammar of the English language. Cambridge: Cambridge University Press.

Jodłowski, S. 1949. "O przysłówkach, partykułach i im pokrewnych częściach mowy" [On adverbs, particles and related parts of speech]. Język polski 29(3). 97-106.

Jucker, A.H. and Y. Ziv. 1998. "Discourse markers: Introduction". In: Jucker, A.H. and Y. Ziv (eds.), Discourse markers. Description and theory. Amsterdam/Philadelphia: John Benjamins.

Kiss, É.K. 2009. “Introduction”. In: Kiss, É.K. (ed.), Adverbs and adverbial adjuncts at the interfaces. Berlin/New York: Mouton de Gruyter. 1-18.

Lenk, U. 1997. "Discourse markers". In: Handbook of pragmatics online. John Benjamins.

Lewis, D. 2006. "Discourse markers in English: A discourse-pragmatic view". In: Fischer, K. (ed.), Approaches to discourse particles. Amsterdam: Elsevier. 43-59.

Martin, J.R. and D. Rose. 2003. Working with discourse: Meaning beyond the clause. New York and London: Continuum.

Mortensen, J. 2012. "Subjectivity and intersubjectivity as aspects of epistemic stance marking”. In: Baumgarten, N., I. Du Bois and J. House (eds.), Subjectivity in language and in discourse. Bingley: Emerald. 229-246.

Nagórko, A. 2012. Podręczna gramatyka języka polskiego [A reference grammar of Polish]. Warszawa: PWN.

Narrog, H. 2012. Modality, subjectivity, and semantic change. A cross-linguistic perspective. Oxford: Oxford University Press.

Nuyts, J. 2001. Epistemic modality, language, and conceptualization: A cognitivepragmatic perspective. Amsterdam: Benjamins.

Ochs, E. 1996. "Linguistic resources for socializing humanity". In: Gumperz, J.J. and S.C. Levinson (eds.), Rethinking linguistic relativity. Cambridge: Cambridge University Press. 407-437.

Piekarczyk, D. 2015. "O potrzebie rozróżniania metatekstu i metajęzyka" [On the need to distinguish between metatext and metalanguage]. In: Korpysz, T. and A. Kozłowska (eds.), Język pisarzy: Problemy metajęzyka i metatekstu [The language of writers: Problems of metalanguage and metatext]. Warszawa: Wydawnictwo Uniwersytetu Kardynała Stefana Wyszyńskiego. 11-27. 
Quirk, R., J. Svartvik, G. Leech and S. Greenbaum. 1985. A comprehensive grammar of the English language. London: Longman.

Schiffrin, D. 1987. Discourse markers. Cambridge: Cambridge University Press.

Schoonjans, S. 2013. "Modal particles: Problems in defining a category". In: Degand, L., B. Cornillie and P. Pietrandrea (eds.), Discourse markers and modal particles. Categorization and description. Amsterdam/Philadelphia: John Benjamins. 133161.

Simon-Vandenbergen, A.-M. and K. Aijmer. 2002/2003. "The expectation marker of course". Languages in Contrast 4(1). 13-43.

Simon-Vandenbergen, A.-M. and K. Aijmer. 2007. The semantic field of modal certainty: A corpus-based study of English adverbs. Berlin/New York: Mouton de Gruyter.

Tokarski, J. 1949. "O kategorii przysłówka" [On the category of adverbs]. Poradnik Językowy 29(2). 14-20.

Traugott E.C. 1995. "The role of the development of discourse markers in a theory of grammaticalization”. Paper presented at ICHL 12, Manchester, UK, August. Available at: <http://www/ traugott/papers/discourse.pdf $>$.

Traugott, E.C. 2007. "Discussion article: Discourse markers, modal particles, and contrastive analysis, synchronic and diachronic". Catalan Journal of Linguistics 6. $139-157$.

Traugott, E. C. 2012. "Intersubjectivisation and clause periphery". English Text Construction 5(1). 7-28.

Tutak, K. 2003. Leksykalne nieczasownikowe wykładniki modalności epistemicznej w autobiografiach [Lexical non-verbal means of expressing epistemic modality in autobiographies], Kraków: Księgarnia Akademicka.

Wajszczuk, J. 2000. "Can a division of lexemes according to syntactic criteria be consistent?” Biuletyn Polskiego Towarzystwa Językoznawczego 55: 20-38.

Wajszczuk, J. 2005. O metatekście [On metatext]. Warszawa: Katedra Lingwistyki Formalnej UW.

Wajszczuk, J. 2010. "Functional class (so called 'part of speech') assignment as a kind of meaning-bound word syntactic formation”. Cognitive Studies/Études Cognitives 10. 15-33.

Weydt, H. 2006. “What are particles good for?” In: Fischer, K. (ed.), Approaches to discourse particles. Amsterdam: Elsevier. 205-217.

Wierzbicka, A. 1971. "Metatekst w tekście" [Metatext in text]. In: Mayenowa, M.R. (ed.), O spójności tekstu. Wrocław: Ossolineum. 105-121.

Wierzbicka, A. 2006. English: Meaning and culture. Oxford: Oxford University Press.

Żabowska, M. 2009. "Hierarchia wyrażeń metatekstowych" [A hierarchy of metatextual expressions]. Linguistica Copernicana 2. 179-189.

\author{
Address for correspondence \\ Agata Rozumko \\ Institute of Modern Languages, University of Białystok \\ ul. Liniarskiego 3 \\ 15-420 Białystok \\ Poland \\ a.rozumko@uwb.edu.pl
}

